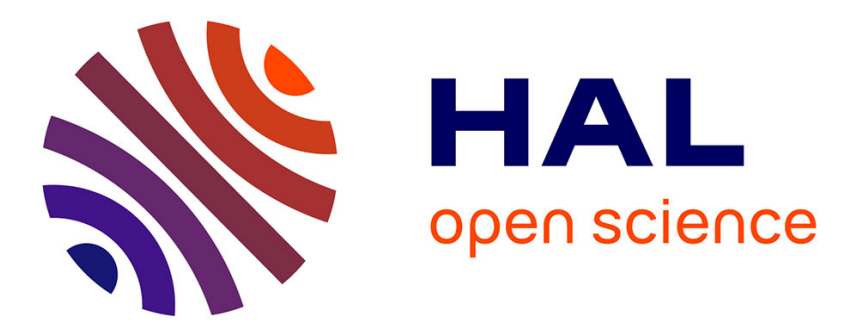

\title{
Thermo-mechanical behavior of energy diaphragm wall: physical and numerical modelling
}

Shengshi Dong, Xiaozhao Li, Anh Minh A.M. Tang, Jean-Michel Pereira, van Tri Nguyen, Ping Che, Zhiyong Xiong

\section{- To cite this version:}

Shengshi Dong, Xiaozhao Li, Anh Minh A.M. Tang, Jean-Michel Pereira, van Tri Nguyen, et al.. Thermo-mechanical behavior of energy diaphragm wall: physical and numerical modelling. Applied Thermal Engineering, 2019, 10.1016/j.applthermaleng.2018.09.054 . hal-02877008v2

HAL Id: hal-02877008 https://hal-enpc.archives-ouvertes.fr/hal-02877008v2

Submitted on 23 Jun 2020

HAL is a multi-disciplinary open access archive for the deposit and dissemination of scientific research documents, whether they are published or not. The documents may come from teaching and research institutions in France or abroad, or from public or private research centers.
L'archive ouverte pluridisciplinaire $\mathbf{H A L}$, est destinée au dépôt et à la diffusion de documents scientifiques de niveau recherche, publiés ou non, émanant des établissements d'enseignement et de recherche français ou étrangers, des laboratoires publics ou privés. 


\title{
1 Thermo-mechanical behavior of energy diaphragm wall: physical \\ 2 \\ and numerical modelling
}

3

4$$
5
$$

7

8

11 Corresponding author:

12 Xiaozhao LI

13

$14 \quad$ Nanjing University

15 No.163 Xianlin Avenue, Nanjing

16210023 Jiangsu Province

17 PR China

18 Email : $\underline{\text { lixz@nju.edu.cn }}$

19 Phone : +86 13951604941 PR China

\author{
Shengshi DONG ${ }^{\mathrm{a}}$, Xiaozhao LI $^{\mathrm{a}}$, Anh Minh TANG ${ }^{\mathrm{b}}$, Jean Michel PEREIRA $^{\mathrm{b}}$, Van Tri
}

NGUYEN ${ }^{\mathrm{b}}$, Ping $\mathrm{CHE}^{\mathrm{c}}$, Zhiyong XIONG ${ }^{\mathrm{a}}$

${ }^{a}$ School of Earth Sciences and Engineering, Nanjing University, Zhugongshan Building, Xianlin Avenue, Nanjing, Jiangsu Province 210023, PR China

${ }^{b}$ Laboratoire Navier, UMR 8205, École des Ponts ParisTech, IFSTTAR, CNRS, UPE, France

c East China Mineral Exploration and Development Bureau, Nanjing, Jiangsu Province 210007, 
20 Abstract: The paper presents a study of the thermo-mechanical behavior of energy diaphragm

21 wall. A physical model, which consists of a small-scale concrete diaphragm wall equipped with

22 a heating exchange pipe, was used. A heating test was performed where hot water (at $50{ }^{\circ} \mathrm{C}$ ) was

23 circulated through a heat exchange pipe for $75 \mathrm{~h}$. The results show that the temperatures in the

24 wall and in the soil increased quickly during the first $20 \mathrm{~h}$ and reached stabilization at the end of

25 the experiment. Heating induced increase of axial strain in the wall and earth pressure at the

26 soil/wall interface. In addition to the experiment, a numerical model, using finite element

27 analysis, was used to predict the behavior of the wall during this experiment. The good

28 agreement between the numerical and the experimental results allows the main phenomena that

29 took place to be explained; heating induces thermal expansion of the wall that results in the

30 modification in stress in the wall and at the soil/wall interface. In addition, since the pipe was

31 located closer to one side of the wall, the thermal expansion of the wall was not homogenous,

32 and the wall bent during heating.

33 Keywords: Thermo-mechanical behavior; Energy diaphragm wall; Physical model; Numerical

34 simulation

35 
 \\ 1. Introduction}

37 A thermo-active (or energy) geostructure is a new-style Groud Source Heat Pump (GHSP) system that consists of conventional geostructures (e.g. pile foundation, tunnel lining, diaphragm wall) with individual or several pipe circuits (high-density polyethylene pipes, HDPE) of primary circuit embedded within to enable heat exchange with the surrounding ground [1]. In winter, heat is extracted from the ground for the purpose of heating and in summer, heat is injected into the ground to provide cooling. Energy geostructures are considered an interesting and promising technology to tackle the increasing energy demands for heating and cooling of

44 buildings and other infrastructures, by making use of it as a local and sustainable source. However, there are still concerns about the thermal exchange, between the structure and the ground, which may induce variation in the stress/strain behavior of the geostructure and, as a consequence, be a threat to its safety and performance. Thus, several research works have been focused on the thermo-mechanical behavior of energy geostructures in order to better understand its stress/strain behavior under combined thermal and mechanical loading [2-8]. However, most of the existing studies are related to the thermo-mechanical behavior of energy

52 piles. The methods used include in situ experiments [9-12], laboratory tests [13-23] and numerical simulations [24-29]. It has been reported that there are significant changes in stress distribution and shaft resistance due to constraints on the thermal expansion/contraction [30]. Although these phenomena are not expected to lead to detrimental consequences, they should be taken into consideration at the design stage. 
58 Few studies of the thermo-mechanical performance of energy diaphragm walls have been 59 published however [31, 32]. It has been suggested that thermally-induced strains and stresses 60 also develop in energy walls [32]. However, their effects are less predictable than in energy piles

61 because of their greater complexity in terms of geometry. Sterpi et al. [32] performed 3D 62 thermo-mechanical Finite Element Analyses (FEA) and concluded that the thermally induced 63 effects on the structure were not negligible and could be observed partly as additional 64 displacements, partly as variations of the internal actions. Bourne-Webb et al. [31] also 65 performed numerical simulations and found that changes to the wall mechanical response were 66 dominated by seasonal temperature changes.

67

68 The most important function of the diaphragm wall is for ground support and seepage control. If 69 there is crack in the wall, the deformation caused by thermal expansion/contraction and lateral 70 soil pressure may aggravate the damage. Some diaphragm walls are also applied for bearing 71 purpose, as a result, the thermally-induced strains and stresses are thus important to be 72 investigated. Numerical analysis have demonstrated an increase of radial contact pressures on 73 the soil-pile interface due to temperature-induced expansion of the pile $[33,34]$. For energy pile, 74 this increase of radial contact pressures could only increase the soil-pile frictional resistance. But 75 for diaphragm wall, due to the existence of excavation at one side of the wall, the pressure 76 change may cause additional deformation after Sterpi et al. [32]. However, the bending moment 77 caused by heating was small and overwhelmed by the effect of environmental thermal boundary 
conditions through numerical analysis by Bourne-Webb et al. [31].

This paper presents a study to evaluate the thermo-mechanical response of an energy diaphragm wall by using physical and numerical modeling. A small-scale energy diaphragm wall was installed in dry sand. Its behavior under thermal loading was monitored using strain, stress and temperature sensors embedded inside/on the wall and also in the surrounding soil. At the same time, its behavior was predicted by using Finite Element Analyses (FEA). The combination of the two methods allows better understanding the thermo-mechanical behavior of an energy diaphragm wall when its temperature is varied.

87

\section{Physical model}

The schematic view of the physical model is shown in Figure 1. A small-scale concrete diaphragm wall (2.00 m high, $1.80 \mathrm{~m}$ wide, and $0.20 \mathrm{~m}$ thick) was installed inside a steel box and the bottom of the wall was in contact with the bottom of the box. The internal height and width of the box are similar to those of the wall. The thickness of the box walls and floor is 25 $\mathrm{mm}$ with other $30 \mathrm{~mm}$ grillage structure outside, which is large enough to consider that the box is rigid. The box was exposed to the indoor air with a controlled temperature of $10 \pm 2^{\circ} \mathrm{C}$ and the heat convection between the surfaces and air is natural convection. Prior to the experiment, the box was filled with dry sand in layers of 0.2-m thickness which were compacted to a density

97 of about $1.62 \mathrm{Mg} / \mathrm{m}^{3}$ (corresponding to a relative density of $80 \%$ and void ratio of 0.63 ). The 98 control of density by layer ensures its uniformity throughout the test specimen. This physical 

identified in other studies [30, 31], will not be captured.

102

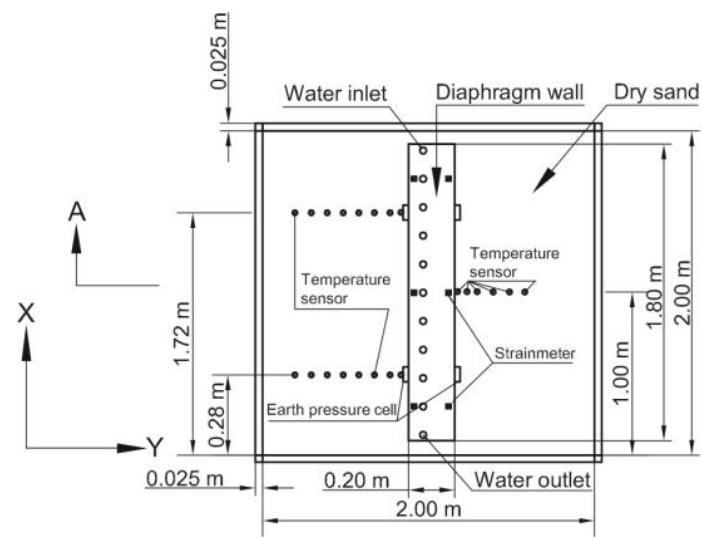

(b)

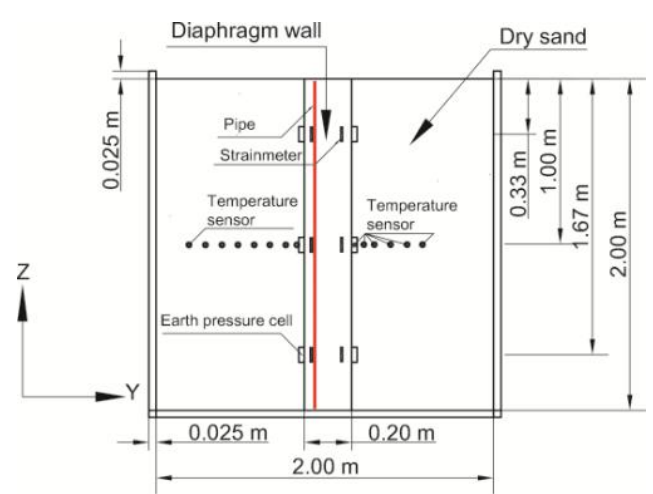

(c)
104

105

106

107

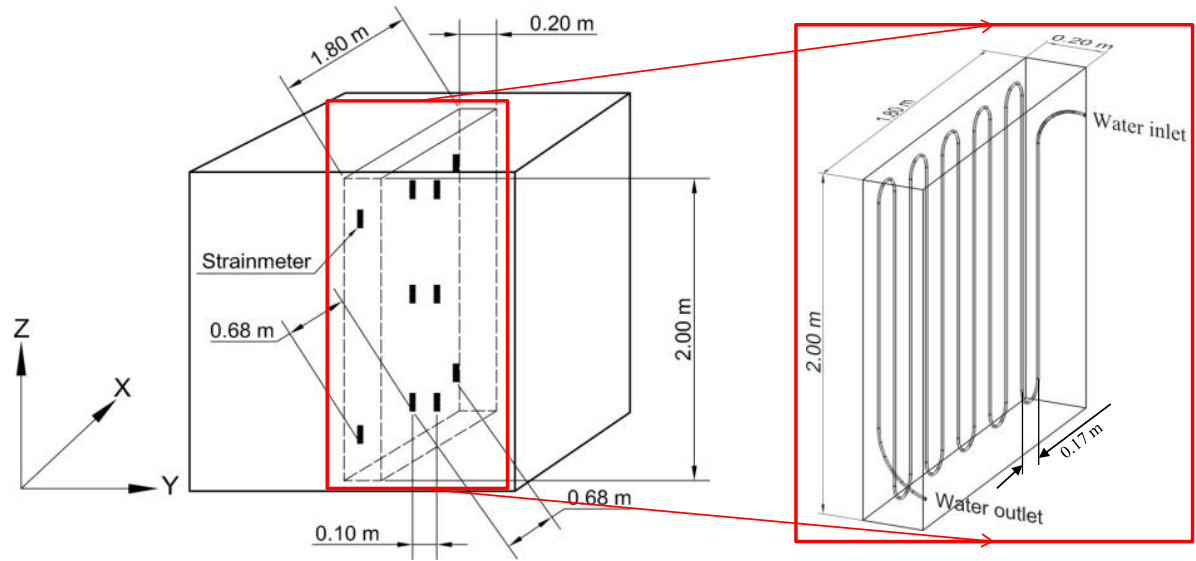

(a)

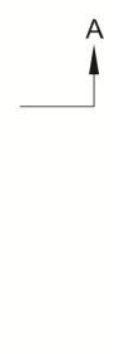

Fig. 1. Schematic view of the experimental setup; (a) 3D view of the physical model with the details of the pipe and strainmeters; (b) Horizontal section at $Z=1.00 \mathrm{~m}$; (c) Section A-A, Vertical section at $\mathrm{X}=1.00 \mathrm{~m}$.

The soil temperature was measured at various locations located on a plane at 1-m depth (see 
Figure $1 c$ ). At this depth, the temperature sensors were distributed in three lines, two on the left-hand side and one on the right-hand side (see Figure $1 b$ ). This allows the soil temperature to be measured at different distances from the diaphragm wall surfaces at the same depth. The

112 diaphragm wall was equipped with high-density polyethylene pipes (10 $\mathrm{mm}$ in external diameter

113 and $8 \mathrm{~mm}$ in internal diameter) to distribute the heating fluid, and various sensors to measure

114 earth pressure, temperature and strain. The details are shown in Figures 1. The pipes were 115 distributed on a plan located at $0.05 \mathrm{~m}$ from the left-hand side surface of the wall and the 116 distance between the pipes was $0.17 \mathrm{~m}$ (see Figure $1 \mathrm{~b}, \mathrm{c}$ ). The details of the pipe arrangement 117 are shown in Figure $1 a$. To measure the earth pressure at the soil/wall interface, 12 sensors were 118 used. These sensors were distributed at three depths $(0.33 \mathrm{~m}, 1.00 \mathrm{~m}$, and $1.67 \mathrm{~m})$ (see Figure $1191 c$ ). At each depth, two sensors were located on each side of the wall (see Figure $1 b$ ). Several 120 strainmeters were tied to the rebars, as shown in Figure $1 a$, to measure the strain at various 121 locations inside the wall. Note that the strainmeters and the earth pressure transducers have 122 integrated with thermistors to measure the temperature. The characteristics of the sensors used 123 are shown in Table 1 and the calibration and correction for the temperature were done by the 124 producers and considered in the data processing. The wall was fabricated outside of the box. 125 After 30 days of curing, it was then installed inside the box and the earth pressure and soil 126 temperature sensors were installed during the compaction of dry sand to fill the box. 127 Table 1. Detailed information of sensors

$\begin{array}{llllll}\text { Sensor } & \text { Market model No. } & \text { Specification } & \text { Capacity } & \text { Sensibility } & \text { Error }\end{array}$




\begin{tabular}{lccccc}
\hline Earth pressure cell & JTM-V2000 & Vibrating wire & $300 \mathrm{kPa}$ & $\leqslant 0.24 \mathrm{kPa}$ & $\leqslant 1 \mathrm{kPa}$ \\
Strainmeter (embedment) & BGK-4200 & Vibrating wire & $3000 \mu \varepsilon$ & $1 \mu \varepsilon$ & $\leq 3 \mu \varepsilon$ \\
& & & & & \\
Temperature sensor & Pt100 & Thermal resistance & $0-300{ }^{\circ} \mathrm{C}$ & $\leq 0.04 \%$ & $0.3{ }^{\circ} \mathrm{C}$ \\
\hline
\end{tabular}

130 After the installation of the experiment, heating was applied to the wall by circulating water

131 through the pipes at a temperature of $50{ }^{\circ} \mathrm{C}$ and with a flow rate of $0.03 \mathrm{~m}^{3} / \mathrm{h}$ for a period of 75

132 h. Beside the temperature evolution which was measured at various locations inside the wall and

133 in the soil, earth pressures at the soil/wall interface and strains inside the wall were also

134 recorded.

\section{Numerical model}

136 In order to predict the mechanical behavior of the wall during this experiment, Finite Element

137 Analysis (FEA) (using ANSYS) was under taken. The 2D mesh, plotted in Figure 2, represents

138 the section shown in Figure 1c. Plane strain conditions were applied corresponding to the

139 boundary conditions of the experiment. The horizontal displacements at the left-hand side and

140 the right-hand side were restrained. The vertical displacement at the bottom of the mesh was

141 also restrained while the stress applied to the top of the mesh was null. The downward vertical

142 displacement of the base of the wall was restrained but the horizontal displacement was not.

143 According to the experimental results, the thermal boundary conditions on the left-hand side and

144 right-hand side have only small influence on the temperature distribution. For this reason, the

145 thermal boundary conditions on these two sides were supposed to be adiabatic. Heat flux was 
equally supposed to be negligible at the bottom boundary. On the top of the model, thermal

147 convection boundary was set with an air temperature of $10{ }^{\circ} \mathrm{C}$ and a convective heat transfer coefficient of $2.5 \mathrm{~W} /\left(\mathrm{m}^{2} . \mathrm{K}\right)([31])$, as it was open to the air.

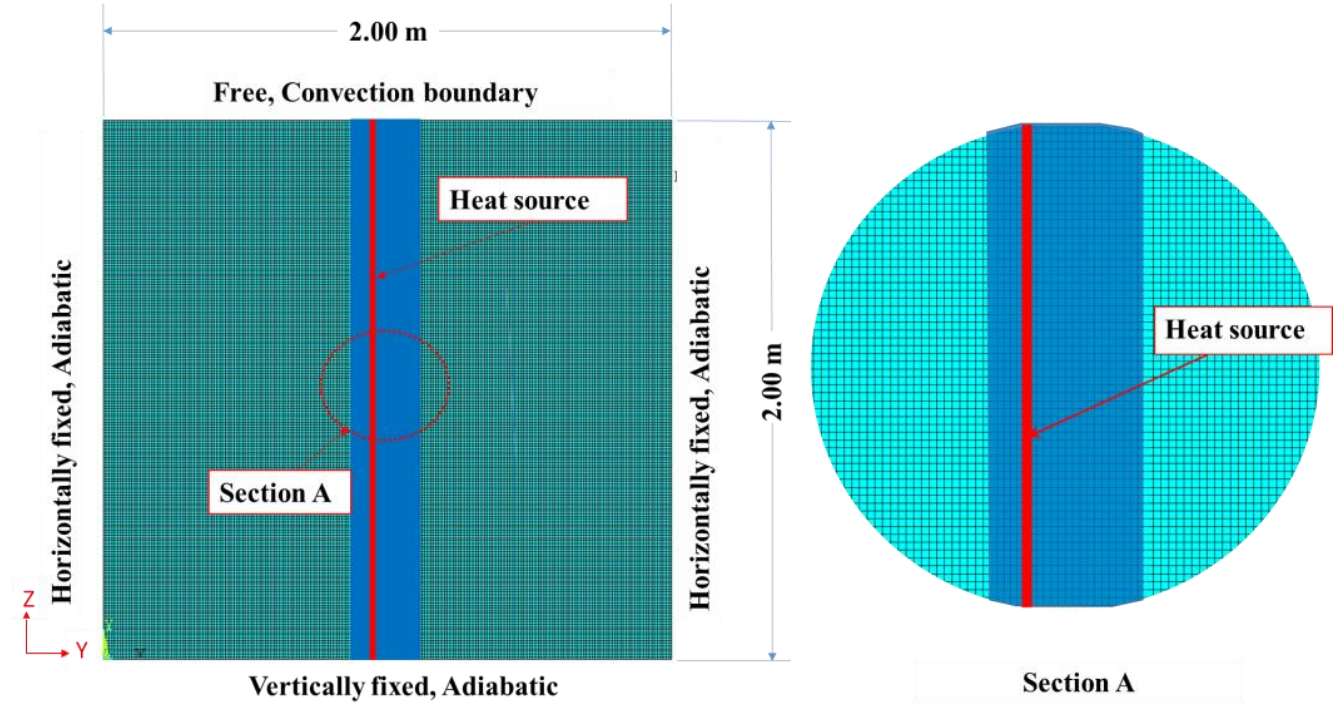

150 Fig.2 Finite element mesh and boundaries conditions used for the numerical simulations.

152 The governing laws used in this study are summarized as follows: $(i)$ only conduction was

153 considered for heat transfer; (ii) the mechanical behavior of the wall was linear elastic while that

154 of the soil was elasto-plastic with the Drucker-Prager yield criterion; (iii) the thermo-mechanical

155 behavior of the wall and soil was linear elastic. The material parameters used for the simulation

156 are shown in the Table 2. Among the parameters, the density, thermal conductivity and specific

157 heat of cement mortar and sand used in the FEA were measured by specialized equipment and

158 also calibrated by one dimensional finite difference method with MATLAB. The Young's

159 modulus and Poisson's ratio of cement mortar were measured by elastic modulus test machine. 
160 Other parameters of cement mortar and sand were taken from the literatures ([35-37]). It should 161 be stated that the coefficient of linear expansion was chosen at $0.6 \times 10^{-5}{ }^{\circ} \mathrm{C}^{-1}$ from literature 162 [35], which gives a typical linear thermal expansion coefficient for dense quartzose sands from $1630.6 \times 10^{-5}{ }^{\circ} \mathrm{C}^{-1}$ to $2.0 \times 10^{-5}{ }^{\circ} \mathrm{C}^{-1}$. The lowest value was chosen to examine the effects of soil 164 thermal expansion on the thermal-mechanical behavior of the wall. For the friction angle, there 165 are literatures which give $30-36^{\circ}$ from loose sand to dense sand $[36,38]$, we chose $30^{\circ}$ as it's 166 density may not easy to compacted to the design stage of the lower depth. According to 167 literature review [36], the dilation angle of dense sand and loose sand are from $0-12^{\circ}$ and $0-10^{\circ}$, 168 respectively. It was chosen at $4^{\circ}$ as an intermediate value in the present study.

170 Table 2. Materials parameters used for simulation

\begin{tabular}{lcc}
\multicolumn{1}{c}{ Parameter } & Cement mortar & Dry sand \\
\hline Thermal conductivity $(\mathrm{W} /(\mathrm{m} . \mathrm{K}))$ & 1.20 & 0.32 \\
Density $\left(\mathrm{Mg} / \mathrm{m}^{3}\right)$ & 1.55 & 1.62 \\
Specific heat $(\mathrm{J} /(\mathrm{kg} . \mathrm{K}))$ & 736 & 700 \\
Young's modulus $(\mathrm{MPa})$ & 12,000 & 50 \\
Poisson's ratio $(-)$ & 0.20 & 0.23 \\
Coefficient of linear expansion $\left(\mu \varepsilon /{ }^{\circ} \mathrm{C}\right)$ & 10 & 6 \\
Cohesion $(\mathrm{kPa})$ & - & 0.1 \\
Friction angle $\left(^{\circ}\right)$ & - & 30 \\
\hline
\end{tabular}


172 In order to simulate the heating phase performed in the experiment, the temperature of the pipes

173 (the vertical line located inside the wall, see Figure 2) was imposed. The initial temperature of

174 the whole system was first fixed at $10^{\circ} \mathrm{C}$ (following the experimental observation). To start the

175 heating phase, the temperature of the pipe was increased from $10{ }^{\circ} \mathrm{C}$ to $48.5^{\circ} \mathrm{C}$ following

176 function (1):

177

$$
T=\frac{2.07 \bullet t+1.1615}{0.0414 \bullet t+0.12323}
$$

178 where $t$ is elapsed time and $T$ is temperature. This choice allows fitting the experimental data of 179 the temperature measured by the sensor that is closest to the pipes $(0.03 \mathrm{~m}$ from the pipe axis, on 180 the left-hand side).

\section{4. Result}

182 In this section, the results obtained from physical test and numerical analysis are compared in 183 the same figures.

184 Figure 3 shows the temperature measured within the wall on the left-hand side in the plane of 185 the wall panel at three different depths $(0.33 \mathrm{~m}, 1.00 \mathrm{~m}$ and $1.67 \mathrm{~m})$ and on the right-hand side at 186 mid-plane ( $\mathrm{x}=1.00 \mathrm{~m}$ Fig.1) versus elapsed time (the origin corresponds to the start of the 187 heating phase). The symbols represent the experimental data (EXP) and the continuous lines 188 represent the numerical results (NUM). Note that in the experiments, more than one sensor 189 exists for one distance (see Figure 1b). As an example, at $\mathrm{y}=0.92 \mathrm{~m}$ on the left-hand side (Figure 
190 3) within the wall, there are three sensors on each depth $(0.33 \mathrm{~m}$ and $1.67 \mathrm{~m})$. The results 191 obtained by these three sensors (showing an increase of temperature from $10^{\circ} \mathrm{C}$ to $45^{\circ} \mathrm{C}$ ) have a 192 difference of about $3-4{ }^{\circ} \mathrm{C}$ at the end of the heating phase. This difference can be explained by 193 the gradual cooling of the fluid while circulating into the pipe which represents an ordinary 194 characteristic condition of energy diaphragm wall.

196

197

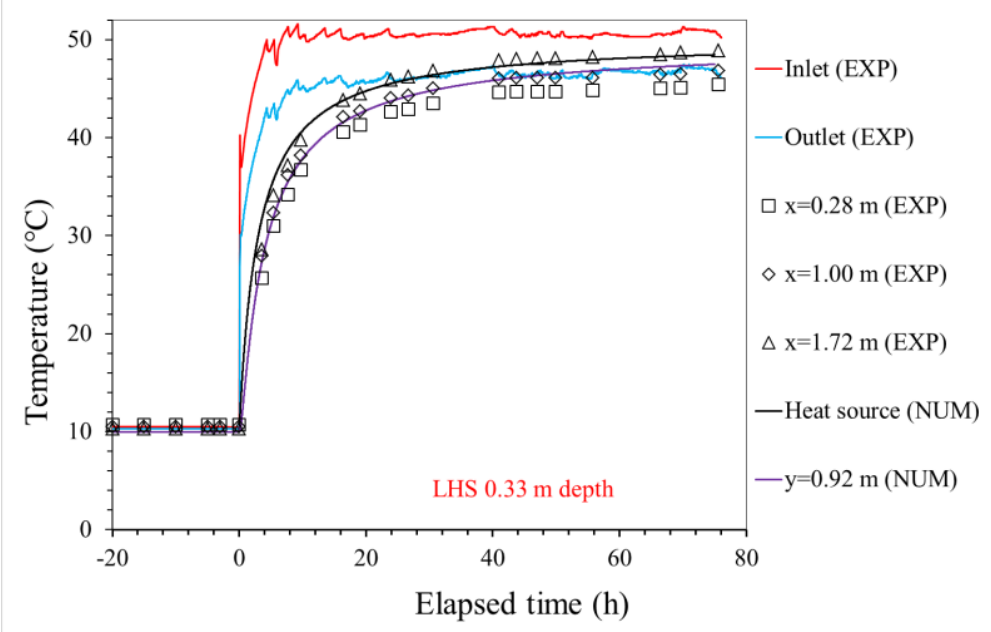

(a)

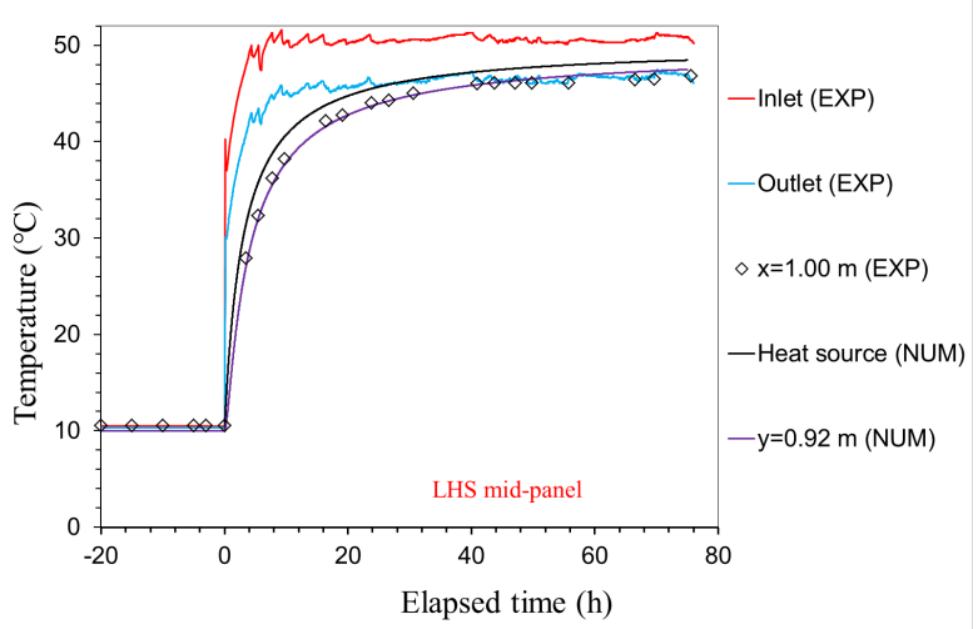

(b) 
207

208

209

210

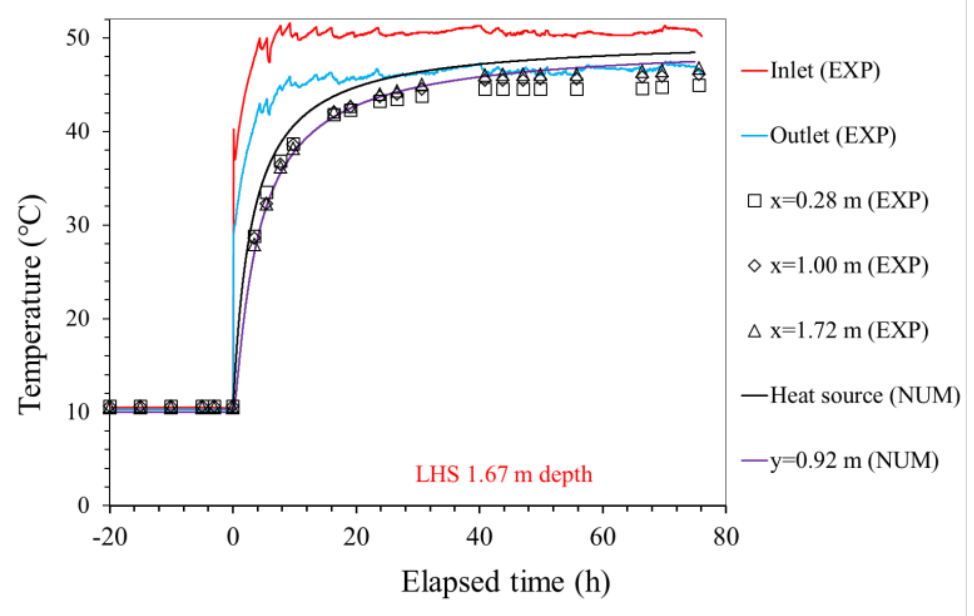

(c)

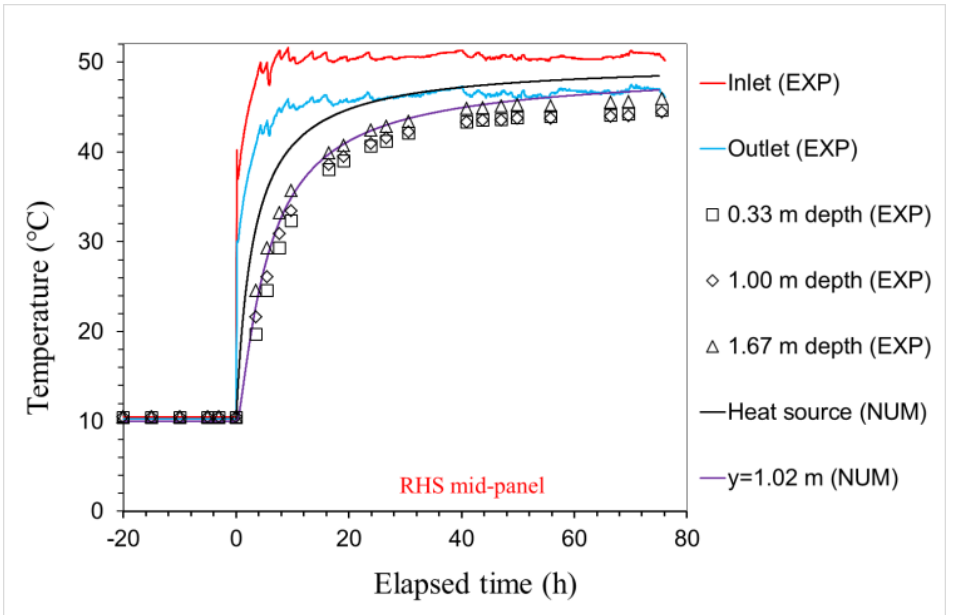

(d)

Fig.3. Temperature versus elapsed time within the wall on the left-hand side along the $\mathrm{x}$ coordinate at depth of (a) $0.33 \mathrm{~m}$ and (b) $1.00 \mathrm{~m}$ and (c) $1.67 \mathrm{~m}$ and on the right-hand side at $\mathrm{x}=1.00 \mathrm{~m}$ for various depths $(\mathrm{d})$

Figure 4 shows the temperature for each single line of sensors embedded in the sand. The agreement between the experimental data and the numerical results confirms that the numerical 2D finite element model is suitable to predict the heat transfer in sand in this experiment. 


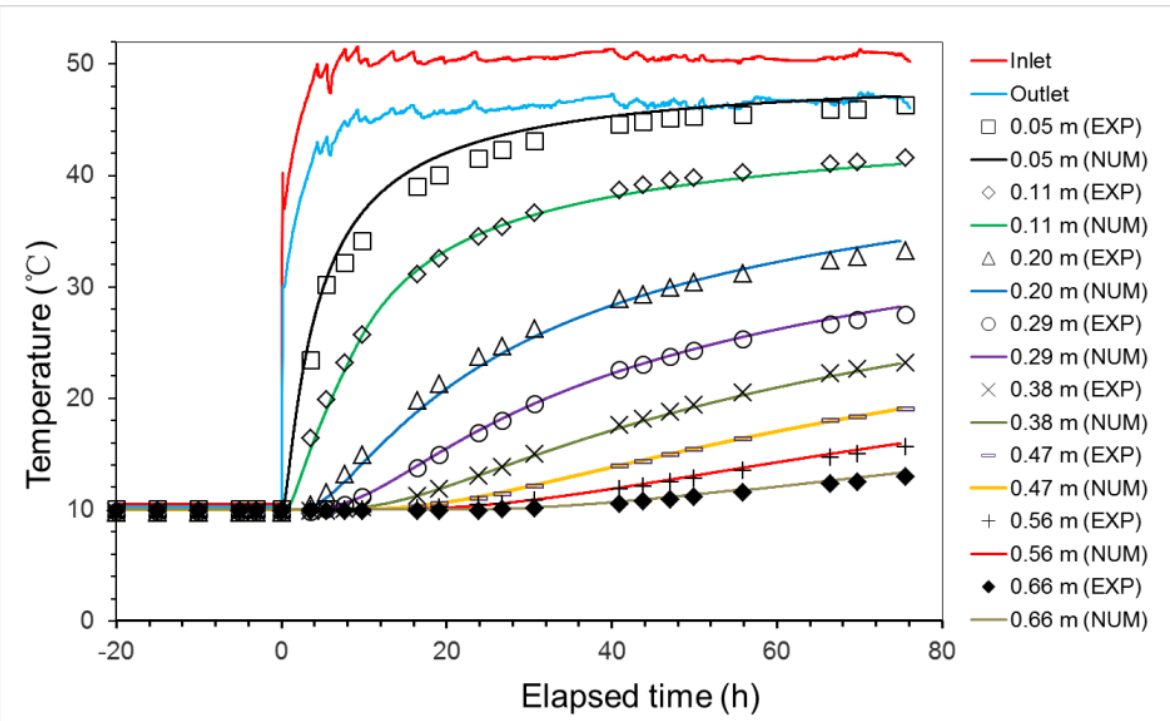

(a)

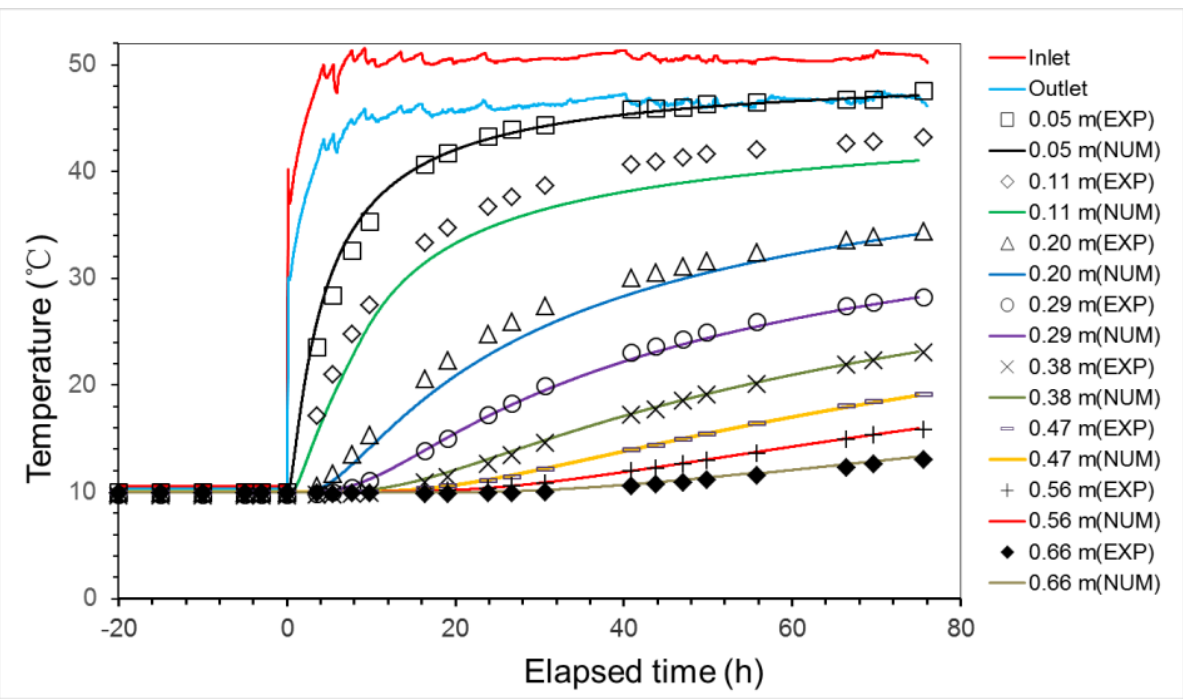




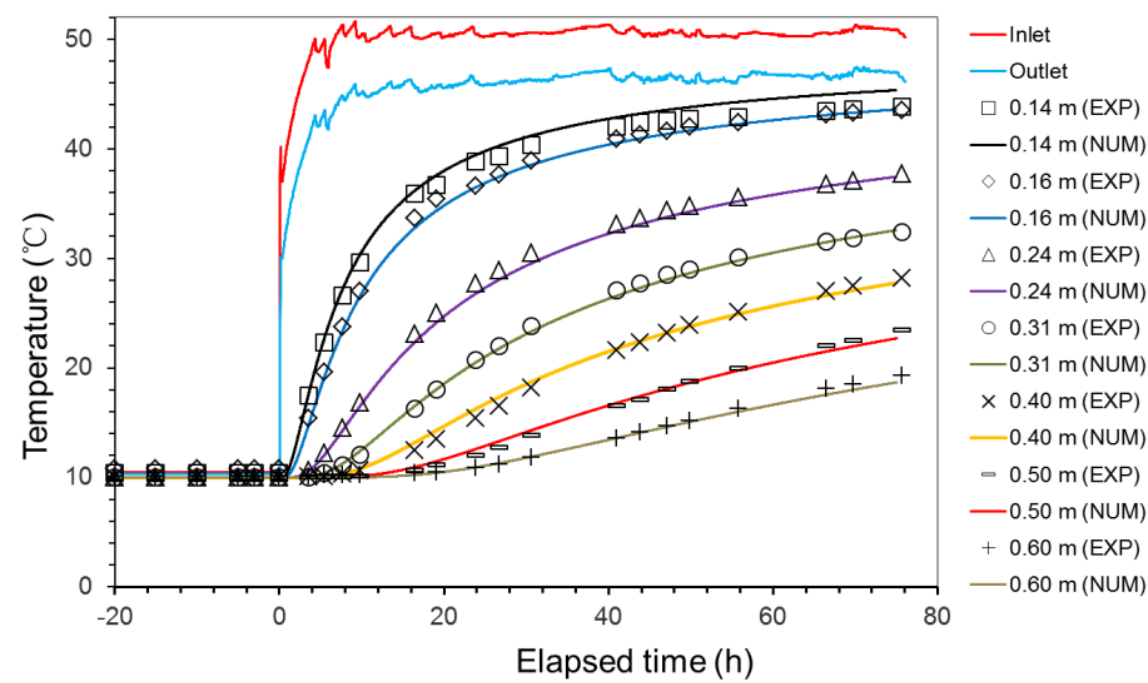

(c)

218 Fig.4. Temperature versus elapsed time in the sand mass at various distances from the pipes axis: (a) on the left-hand side at $\mathrm{x}=0.44 \mathrm{~m}$; (b) on the left hand side at $\mathrm{x}=1.56 \mathrm{~m}$; (c) and on the

220 right-hand side at $\mathrm{x}=1.00 \mathrm{~m}$.

222 Figure 5 shows the temperature profile measured at various moments. It can be seen that at a 223 given time, the temperature at a location closer to the pipe is higher. This plot allows two zones 224 to be distinguished: inside the wall, the temperature gradient is smaller than in the soil. That can 225 be explained by the thermal conductivities of these materials and the boundary conditions: the 226 wall, made of cement, is more conductive than the sand and therefore, the temperature gradient 227 is then smaller. 


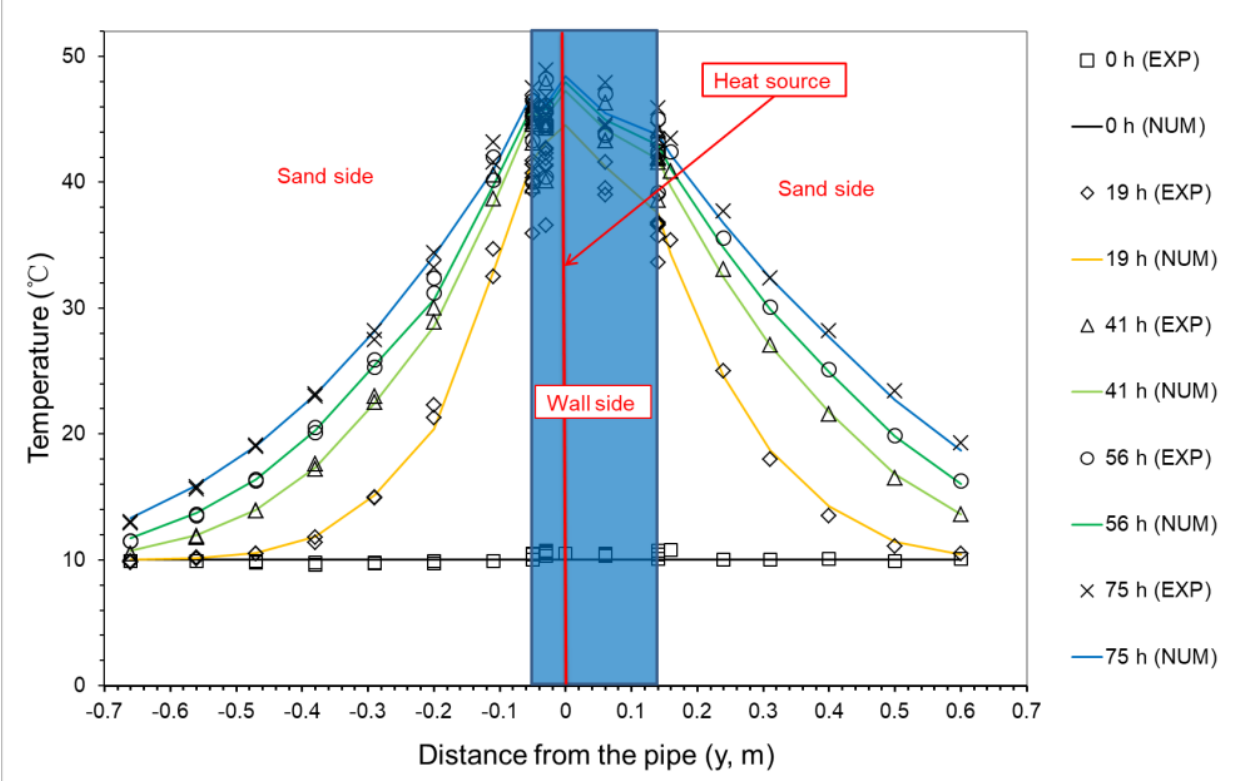

229 Fig.5 Temperature versus distance from the pipe at various elapsed times in the middle of the

230 panel $(\mathrm{z}=1.00 \mathrm{~m})$

232 The numerical results shown in Figures 3, 4 and 5 are in good agreement with the experimental

233 results. That confirms, in this experiment, heat transfer is mainly governed by heat conduction

234 (as considered in the numerical simulation). This agreement confirms also that the thermal

235 boundary conditions used in the simulation are acceptable. In addition, as a 2D mesh was used

236 in the simulation, the numerical results should be compared with the mean values obtained in the

237 experiments with various sensors located at the same distance. The non-uniform of the

238 temperature distribution along the $\mathrm{X}$ direction (observed from the experiments) can be ignored

239 in the numerical model. 
Figure 6 shows the vertical strain (Z direction, see Figure 1a) measured at various x coordinates by the strainmeters. Note that all the strainmeters on the left-hand side (Figure 6a, 6b and 6c) are located $0.03 \mathrm{~m}$ from the pipe. The results show similar trends for all sensors; a rapid increase of 244 strain during the first $20 \mathrm{~h}$ (corresponding to the increase of fluid temperature during the experiment) followed by a more stable phase. The final strain is in the range of 50-70 $\mu \varepsilon$ (except one sensor at $0.33-\mathrm{m}$ depth). The three sensors located at $0.33-\mathrm{m}$ depth show larger strain 247 variation than those at $1.67-\mathrm{m}$ depth; there is only one sensor located at $1.00-\mathrm{m}$ depth. On the 248 right-hand side (Figure 6d), only one sensor was used for each depth. Note that these sensors are 249 located $0.06 \mathrm{~m}$ to the right-hand side of the pipes. The results obtained by these sensors are quite 250 similar showing a quick increase during the first $20 \mathrm{~h}$ and stabilization at $55-65 \mu \varepsilon$. These 251 discrepancies in strains can be directly linked to the heterogeneity of temperature distribution of 252 the wall shown in Figure 6.

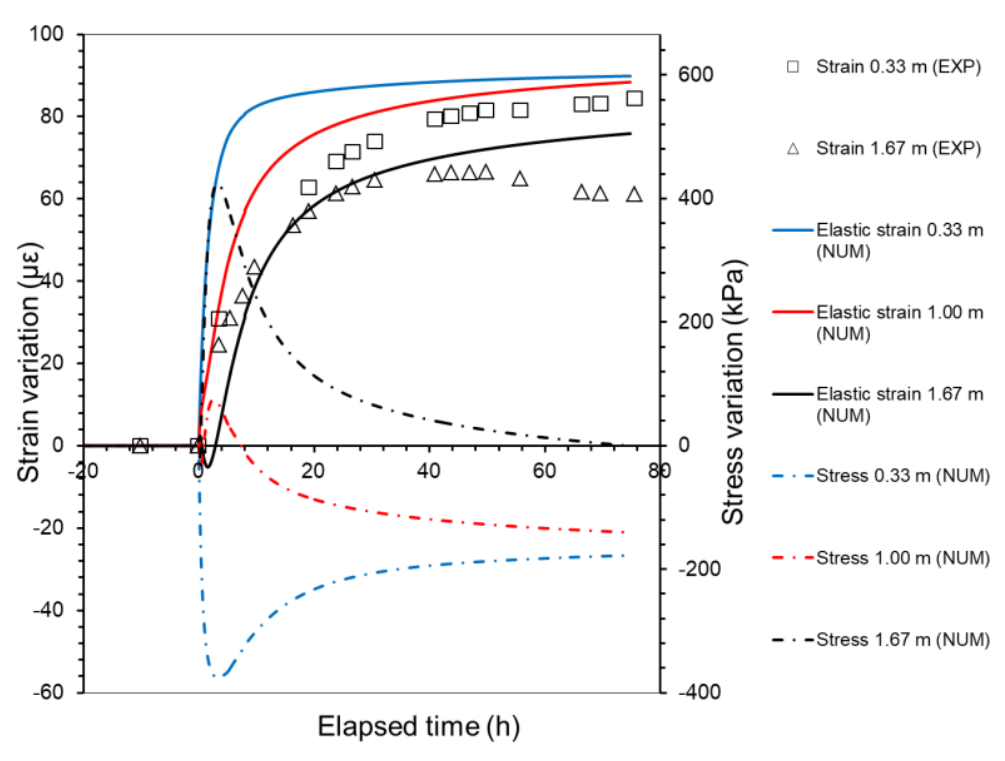




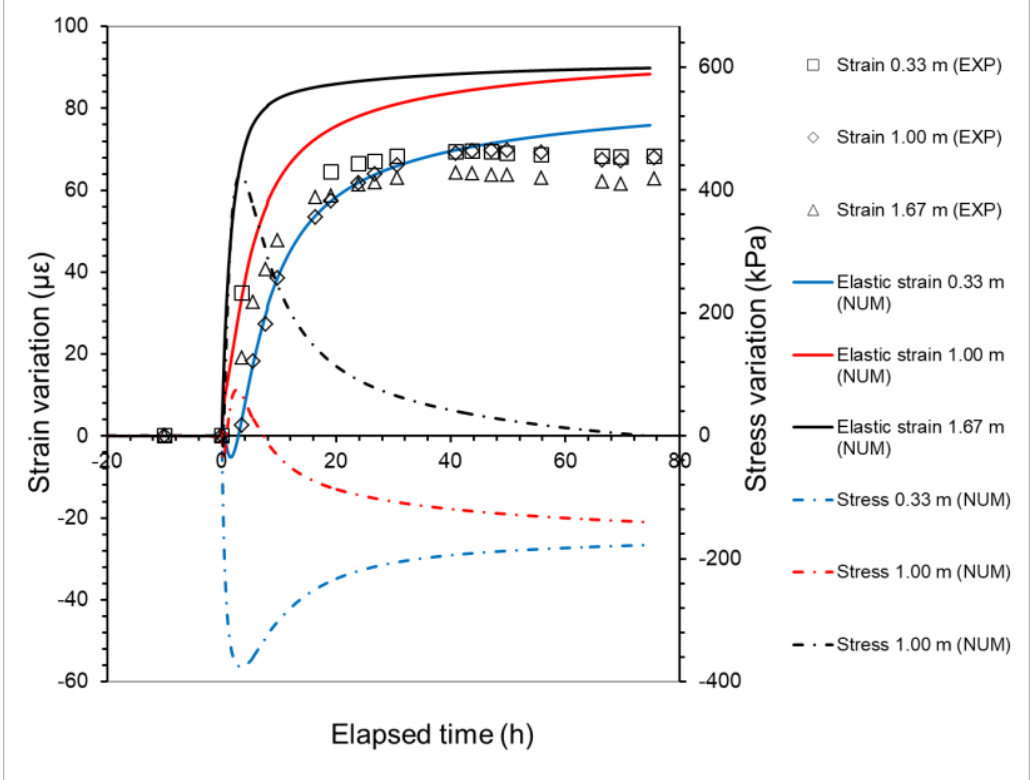

(b)

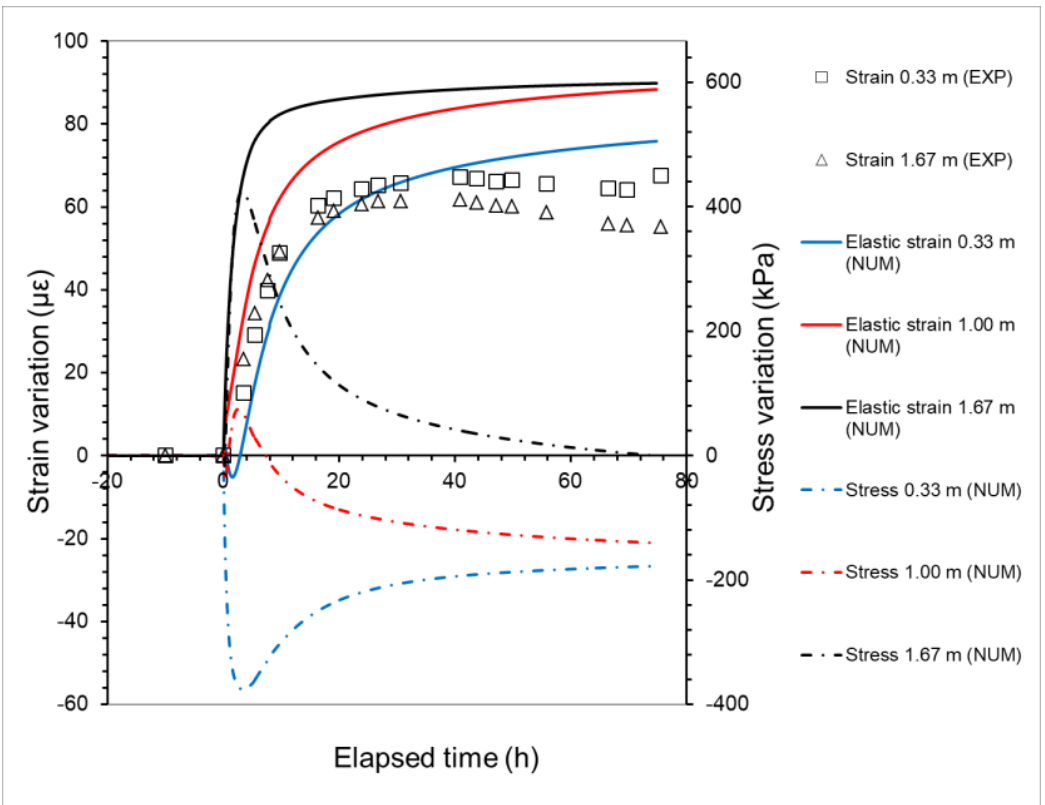


262 Fig.6. Vertical strain and stress versus elapsed time on the left-hand side at (a) $\mathrm{x}=0.28 \mathrm{~m}$; (b) $\mathrm{x}$ $263=1.00 \mathrm{~m} ;(\mathrm{c}) \mathrm{x}=1.72 \mathrm{~m} ;(\mathrm{d})$ and on the right hand at $\mathrm{x}=1.00 \mathrm{~m}$.

(d)

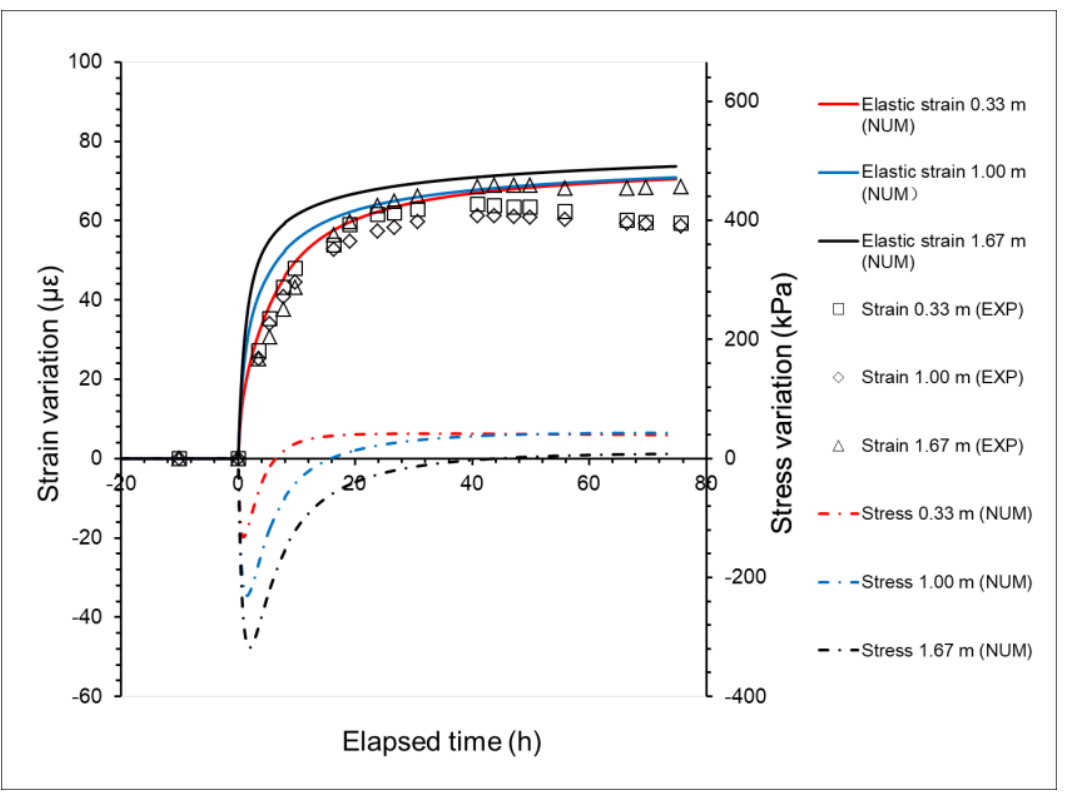

264

265

266 The vertical strains predicted by the numerical analysis are also shown in the Figure 6 (positive

267 strain corresponds to expansion). On the left-hand side, the numerical analysis show that heating 268 induced a quick expansion at $0.33-\mathrm{m}$ depth followed by stabilization at $80 \mu \varepsilon$. This result is 269 similar to that obtained by the experiment. However, for the other depth $(1.67 \mathrm{~m})$, the numerical 270 analysis shows a contraction during the first hours. This contraction was then followed by 271 expansion and the final values are also similar to the experimental ones. The trend of the vertical 272 strains on the right-hand side shows a good agreement between the numerical and the 273 experimental results. 
275 The following mechanisms can be mentioned to explain these results (see also the vertical stress

276 variation plotted in the Figure 6). The high value of vertical stress is related to the temperature

277 gradient in the wall thickness (see Figure 1). When the temperature of the wall increases, the

278 vertical strain increases by the thermal expansion. As the boundary condition at base of the

279 domain was vertically fixed, the deformation of the wall could only expand upward. On the

280 left-hand side, the heating rate is higher (so during the first $20 \mathrm{~h}$ ), thermal expansion on the

281 left-hand side is higher than the right-hand side. This thermal expansion in the left-hand side

282 was then "restrained" by the right-hand side of the wall. At the same time, the vertical expansion

283 of the wall mobilizes the shaft friction along its interface in contact with the soil mass. That

284 mobilized shaft friction tends to prevent the wall vertical expansion, increasing then the vertical

285 stress inside the wall. On the other hand, the sensors located at larger depths $(1.67 \mathrm{~m})$ are

286 subjected to higher increase of vertical stress. That explains the compression of the wall during

287 the first hours on the left-hand side at large depths and tensile stress on the right-hand side.

288

289 Figure 7 shows the normal stress on soil-wall interface versus elapsed time at various locations.

290 The initial value of the lateral earth pressure is approximately $1 \mathrm{kPa}$ at $0.33 \mathrm{~m} \mathrm{depth}, 5 \mathrm{kPa}$ at

$2911.00 \mathrm{~m}$ depth and $9 \mathrm{kPa}$ at $1.67 \mathrm{~m}$ depth. On the left-hand side (Figure 7a), at 0.33-m depth,

292 there is only one transducer. The measurement shows a quick increase of the earth pressure

293 following the heating phase, and the value at stabilization is approximately $4 \mathrm{kPa}$. At $1.00-\mathrm{m}$

294 depth, there are two sensors both showing a quick increase of the earth pressure and the final

295 values are approximately $11 \mathrm{kPa}$. The discrepancies between the two sensors are around $1 \mathrm{kPa}$. 
297 conclusion, for the left-hand side, the variation of earth pressure is more significant at greater depth during heating.

299

300
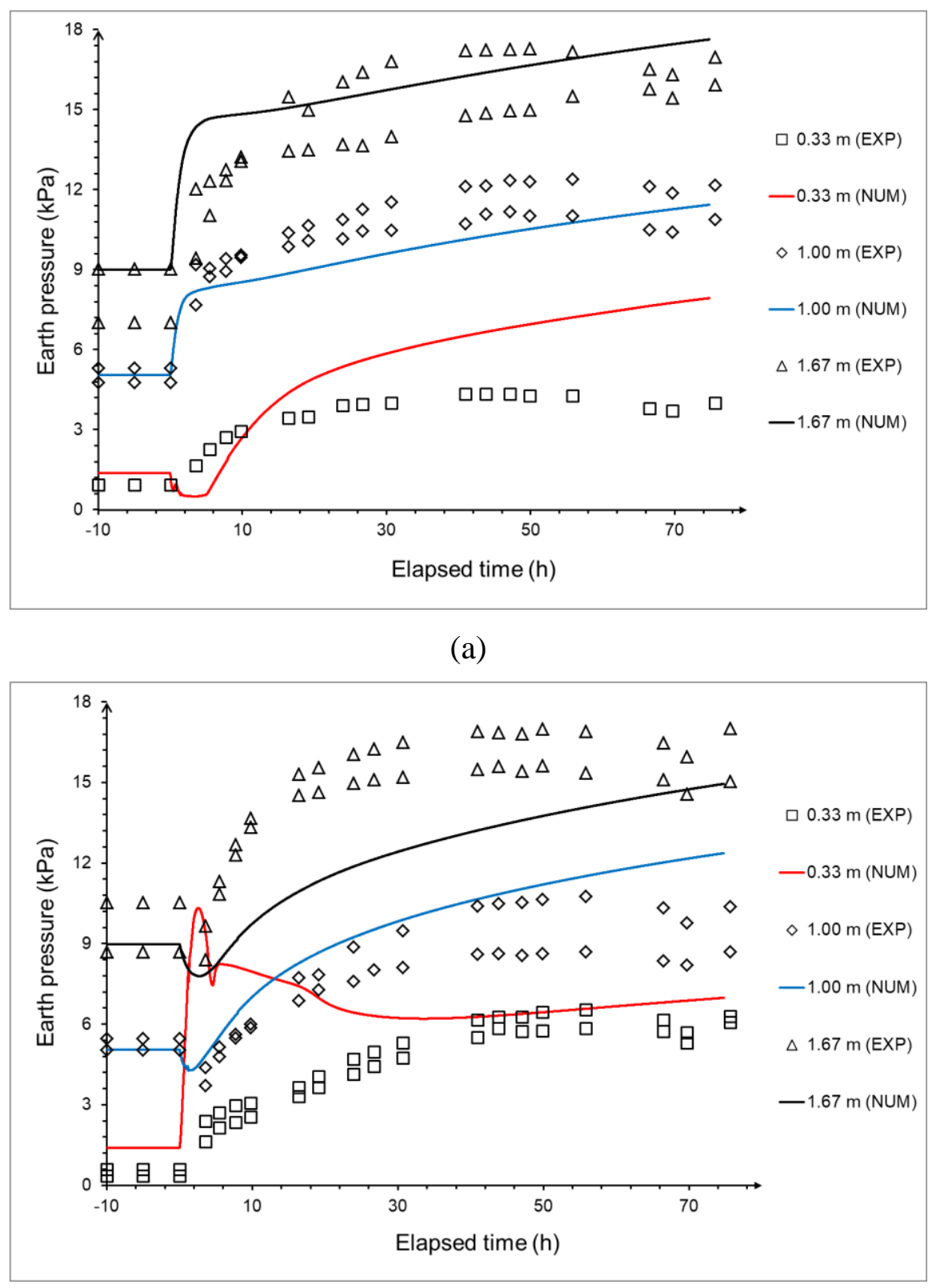

303

Fig.7 Stress versus elapsed time at various depths on the left-hand side (a) and on the 304 right-hand side (b).

(a)

(b) 
The general trend observed on the right-hand side is different at the start of heating (Figure $7 \mathrm{~b}$ ).

307 At $0.33-\mathrm{m}$ depth, the two earth pressure sensors show quick increase with the heating and the 308 final average value equals $6 \mathrm{kPa}$, with a discrepancy of less than $0.5 \mathrm{kPa}$. At $1.00-\mathrm{m}$ depth, both 309 sensors show first a decrease of the earth pressure during the first hours of heating. These values 310 increase and reach around $9 \mathrm{kPa}$ at the end (with a discrepancy of $1 \mathrm{kPa}$ ). For the sensors at 311 1.67-m depth, the earth pressure increases with the heating and reaches $15-17 \mathrm{kPa}$ at the end. It 312 could be seen there are still increase of pressure on both side at end of the test, this may due to a 313 minor problem with the measurement.

315 The numerical results corresponding to the sensors at 1.00-m and 1.67-m depths show good 316 agreement with the experimental ones for both sides. Even the decrease of the earth pressure at 317 1.00-m depth on the right-hand side was well predicted. However, the numerical results 318 corresponding to lower depth $(0.33 \mathrm{~m})$ are significantly different from the experiment values.

319 On the left-hand side, the numerical simulation shows a decrease of earth pressure during the 320 first hour, which was not observed in the experiment. On the right-hand side, the earth pressure 321 spikes during the first hour, which was not observed in the experiment. These problems would 322 be explained by the mechanical behavior of the sand in higher deflections [36, 39] under low 323 stress level that could not be well predicted by FEA. This could also explain why was there 324 reasonable accord before heating. 
In order to better understand the results on the change of earth pressure (shown in Figure 7), the

327 deformed mesh ( $5 \mathrm{~h}$ after the starting of the heating) is shown in Figure 8. Heating induces

328 thermal expansion of the wall. That tends to increase the earth pressure at the soil/wall interface.

329 However, as the pipes were located closer to the left-hand side, the temperature distribution is

330 non-uniform. With the temperature on the left-hand side increasing more quickly than that on

331 the right-hand side. This induces a bending of the wall that can be seen clearly in the Figure 9.

332 This bending contributes also to the modification of the earth pressure. Besides the increase of

333 earth pressure related to the wall expansion, the wall bending decreases the earth pressure

334 (mostly on the top) on the left-hand side and increases that on the right-hand side. That explains

335 why the increase of earth pressure at $0.33-\mathrm{m}$ depth on the right-hand side is higher than those at

336 higher depth and the order is opposite on the left-hand side. In addition, the bending of the wall

337 also explains the decrease of earth pressure observed at $1.00-\mathrm{m}$ depth on the right-hand side

338 during the first few hours. 


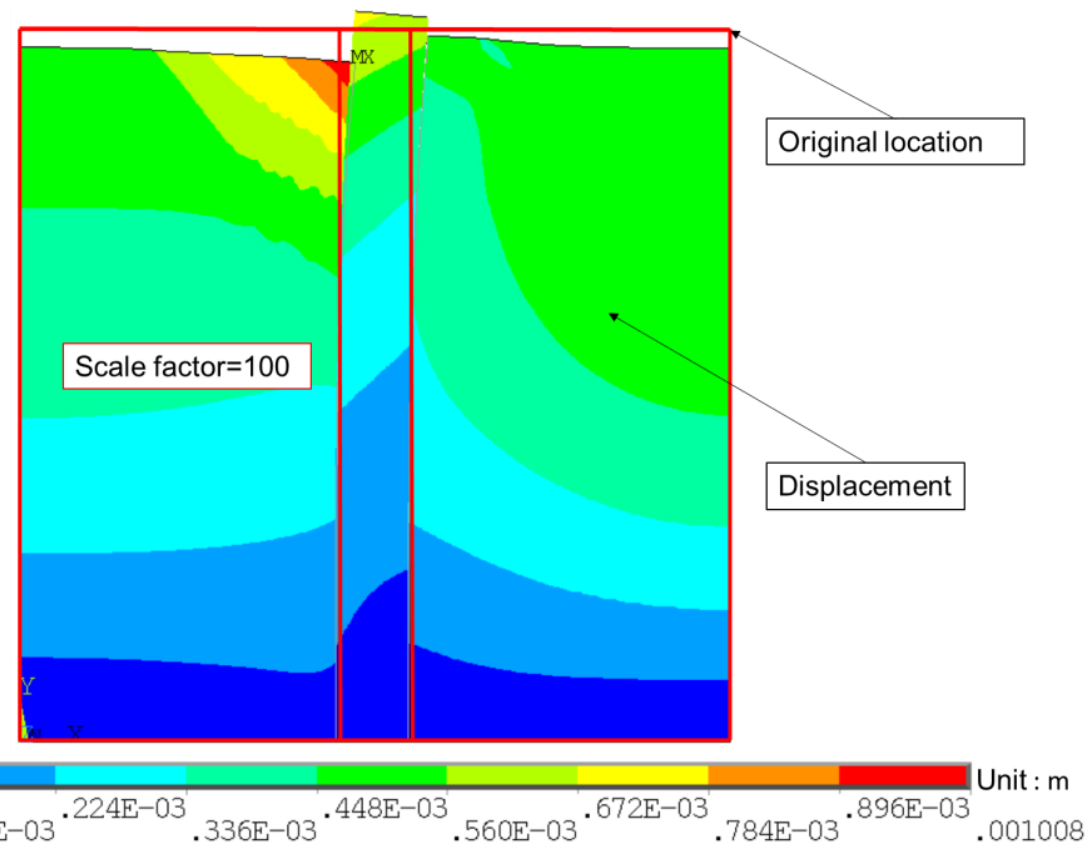

340 Fig.8 Deformed mesh at 5 hours (the color represents the sum of Y and Z displacement 341 vectors).

\section{Discussion}

344 In the present work, a 1-g physical model was used to study the thermo-mechanical behavior of

345 an energy wall panel. Strainmeters were used to capture the axial strain inside the wall and earth

346 pressure transducers were used to capture the normal stress at the soil/wall interface. This

347 approach has been used in various studies to investigate the mechanical behavior of 348 geostructures [40-42]. The results obtained in the present work show that this method could be 349 also used to investigate the thermo-mechanical behavior of energy geostructures.

351 As far as the numerical model was concerned, the present study used a plane strain 2D FE model 352 that approximates the conditions of the experiment. Even if this model could not capture the 3D 
heterogeneity of the temperature distribution, related to the difference between the inlet and

354 outlet temperatures, a generally good agreement between the numerical and the experimental

355 results can be observed. This confirms also that the boundary conditions and the constitutive

356 laws used in this model are suitable for this case. Note that, for studying the thermal behavior of

357 energy geostructures, usually only heat conduction is considered for heat transfer in the soil and

358 in the reinforce concrete [29, 30, 43] unless ground water flow is present [7, 44, 45]. Heat

359 convection in heat exchange pipe was discussed in the literature [32] and the heat transfer

360 mechanism between the fluid and the pipe is more complex to be simulated [46, 47]. The

361 hypothesis of elastic deformation is usually used for gravel soils in numerical simulation

362 because it is in agreement with experimental observations [27, 29, 48, 49]. In some cases where

363 clayey soils were considered, more complex constitutive laws maybe required [50-53]. As

364 mentioned above, to simplify the model, the heat exchange pipe is often represented by a line

365 with controlled temperature [26]; The thermo-mechanical behavior of the soil was assumed to

366 be elastic and the effect of temperature on the soil mechanical properties was ignored.

367

368 Both numerical and experimental results obtained in the present work evidence that heating the

369 diaphragm wall induces thermal expansion and this increases the lateral earth pressure applied

370 on the wall surface. The lateral earth pressure could be three times larger than the initial stress

371 value under low stress level. This variation seems to have a significant contribution to the

372 vertical stress within the wall. Previous studies on energy pile indicate that radial contact 
373 pressures typically increase less than $5 \mathrm{kPa}$ along $20 \mathrm{~m}$ depth of the pile under an increase of $25^{\circ} \mathrm{C}$

374 of the pile temperature $[33,34]$. In real scale structures, the height to width ratio could be much

375 higher than the ratio in this physical study (equal to 10). As a result, the increase of lateral earth

376 pressures might be negligible with respect to the variations of vertical stresses. However, for an

377 energy pile, the increase of this pressure is almost homogenous because the layout of the pipes is

378 usually symmetric. For diaphragm walls, the behavior is more complex and strongly depends on

379 the distribution of the heat exchange pipes inside the wall. The eccentric position of the heat

380 exchanger loop caused a temperature gradient across the wall thickness, which leads to wall

381 bending. This phenomenon exists also in the wall that is not fully embedded [31], since the

382 temperature condition on the soil side is different from the temperature condition on the

383 excavation side. This represents an additional contribution to thermally-induced vertical strains

384 that are not uniform on the two sides of the wall.

385

386 6. Conclusions

387 The thermo-mechanical behavior of energy wall panel during heating was investigated using 388 both physical and numerical models. The following conclusions can be drawn:

390 - Heating induces thermal expansion of the wall. The vertical thermal expansion mobilizes 391 the shaft friction between the soil and the wall and then modifies the axial stress state inside 392 the wall. Horizontal expansion increases the earth pressure at the soil/wall interface, and 

wall.

395 - As the pipe layout was not symmetric, thermal expansion bends the wall resulting in 396 different stress/strain response between the two sides.

397 - A short-term heating of the wall shows a significant temperature gradient across the wall thickness. As a result, significant stress/strain variation is generated within the wall during 399 the first few hours.

400 - The numerical model using an elastic law for the thermo-mechanical behavior of soil is 401 appropriate to predict the behavior of the wall under thermal loading. There is however 402 some discrepancy between experiment and numerical results that requires a deeper investigation, i.e. soil behavior at low stress level, 3D effect in the numerical model, etc.

404 - In spite of the temperature difference between the outlet and inlet fluid temperature, that 405 induced a non-uniform temperature distribution inside the wall, a 2D numerical model seems appropriate to predict the main features of the panel's thermo-mechanical behavior $407 \quad$ observed by physical model.

\section{Acknowledgement}

410 This research was supported by the National Natural Science Foundation of China (grant

411 number 41272314); and Science and Technology Project of Suzhou (grant number

412 SYG201451); and the European Commission via the Marie Curie IRSES project GREAT

413 'Geotechnical and geological Responses to climate change: Exchanging Approaches and 
414 Technologies on a world-wide scale' (grant number FP7-PEOPLE-2013-IRSES-612665).

415 Thanks are also due to Yinkang Zhou from Nanjing University for valuable discussion.

417 Reference

418 [1] Brandl H (2006) Energy foundations and other thermo-active ground structures.

GEOTECHNIQUE 56(2): 81-122. doi: 10.1680/geot.2006.56.2.81

[2] Laloui L, Nuth M (2008) Investigations on the mechanical behaviour of a Heat Exchanger Pile. In: Deep Foundations On Bored And Auger Piles, Proceedings (No. LMS-CONF-2009-003, pp 343-347). Crc Press-Taylor \& Francis Group, 6000 Broken Sound Parkway Nw, Ste 300, Boca Raton, Fl 33487-2742 Usa.

[3] Chuang YU, Pan LY, Liu SY, Cai YQ (2009) Working mechanism and application of heat exchanger piles. Yantu Lixue/rock \& Soil Mechanics 30(4):932-937. (In Chinese)

[4] Péron H, Knellwolf C, Laloui L (2011) A method for the geotechnical design of heat exchanger piles In: Proceedings of the Geo-Frontiers 2011 Conference, Jie H, Daniel E, Alzamora, PE ASTM, Geotechnical Special Publications (GSP) 211:470-479.

[5] Boënnec O (2009) Piling on the Energy. Geodrilling International 150:25-8.

[6] Dupray F, Li C, Laloui L (2014) Heat-exchanger piles for the de-icing of bridges. Acta Geotech 9:413-423. doi: 10.1007/s11440-014-0307-2

[7] Suryatriyastuti ME, Mroueh H, Burlon S (2013) Impact of transient heat diffusion of a thermoactive pile on the surrounding soil. In: Laloui L, Di Donna A (eds.) Energy Geostructures: Innovation in Underground Engineering. ISTELtd. and John Wiley \& Sons 
Inc, 193-209.

[8] Kürten S, Mottaghy D, Ziegler M (2015) A new model for the description of the heat transfer for plane thermo-active geotechnical systems based on thermal resistances. Acta Geotech 10:219-229. doi: 10.1007/s11440-014-0311-6

[9] Laloui L, Nuth M, Vulliet L (2006) Experimental and numerical investigations of the behaviour of a heat exchanger pile. Int J Numer Anal Met 30(8):763-781. doi: 10.1016/S1571-9960(05)80040-0

[10] Bourne-Webb PJ, Amatya B, Soga K, et al (2009) Energy pile test at Lambeth College, London: geotechnical and thermodynamic aspects of pile response to heat cycles. Géotechnique 59(3):237. doi: 10.1680/geot.2009.59.3.237

[11] McCartney JS, Murphy KD (2012) Strain Distributions in Full-Scale Energy Foundations (DFI Young Professor Paper Competition 2012). DFI Journal-The Journal of the Deep Foundations Institute 6(2):26-38. doi:10.1179/dfi.2012.008

[12] Murphy KD, McCartney JS, Henry KS (2015) Evaluation of thermo-mechanical and thermal behavior of full-scale energy foundations. Acta Geotech 10(2):179-195. doi: $10.1007 / \mathrm{s} 11440-013-0298-4$

[13] Laloui L, Cekerevac C (2008) Non-isothermal plasticity model for cyclic behaviour of soils. Int J Numer Anal Met 32(5): 437-460. doi:10.1002/nag.629

[14] McCartney JS, Rosenberg JE, Sultanova A (2010) Engineering performance of thermo-active foundation systems. In: Goss CM, Kerrigan JB, Malamo J, McCarron MO, Wiltshire RL (eds) GeoTrends: the Progress of Geological and Geotechnical Engineering 
in Colorado at the Cusp of a New Decade (GPP 6), 27-42.

[15] McCartney JS, Rosenberg JE (2011) Impact of heat exchange on the axial capacity of thermo-active foundations. In: Han J, Alzamora DE (eds) Proceedings of geo-frontiers 2011 (GSP 211). ASCE, Reston, VA, 488-498

[16] Kalantidou A, Tang AM, Pereira J-M, Hassen G (2012) Preliminary study on the mechanical behaviour of heat exchanger pile in physical model. Géotechnique 62(11):1047-1051. doi: 10.1680/geot.11.T.013

[17] Stewart MA, McCartney JS (2013) Centrifuge modeling of soil-structure interaction in energy foundations. J Geotech Geoenviron 140(4):04013044. doi: 10.1061/(ASCE)GT.1943-5606.0001061

[18] Yavari N, Tang AM, Pereira J-M, Hassen G (2014) Experimental study on the mechanical behaviour of a heat exchanger pile using physical modelling. Acta Geotech 9(3):385-398. doi: 10.1007/s11440-014-0310-7

[19] Kramer CA, Ghasemi-Fare O, Basu P (2015) Laboratory thermal performance tests on a model heat exchanger pile in sand. Geotech Geol Eng 33(2):253-271. doi: 10.1007/s10706-014-9786-Z

[20] Goode III JC, McCartney JS (2015) Centrifuge modeling of end-restraint effects in energy foundations. J Geotech Geoenviron 141(8):04015034. doi: 10.1061/(ASCE)GT.1943-5606.0001333

[21] Yavari N, Tang A.M, Pereira, J-M, Hassen G (2016) Mechanical behaviour of a small-scale energy pile in saturated clay. Géotechnique 66(11):878-887. 
doi:10.1680/geot./15-T-026

[22] Yavari N, Tang AM, Pereira J-M, Hassen G (2016) Effect of temperature on the shear strength of soils and soil/structure interface. Can Geotech J 53(7):1186-1194. doi: 10.1139/cgj-2015-0355

[23] Nguyen VT, Tang AM, Pereira J-M (2017) Long-term thermo-mechanical behavior of energy pile in dry sand. Acta Geotech 1-9. doi:10.1007/s11440-017-0539-z

[24] Laloui L, Nuth M (2005) Numerical modelling of the behaviour of a heat exchanger pile. Revue européenne de génie civil 9(5-6): 827-839.

[25] Rotta Loria AF, Gunawan A, Shi C, et al (2015) Numerical modelling of energy piles in saturated sand subjected to thermo-mechanical loads. Geomech Eng En 1:1-15. doi:10.1016/j.gete.2015.03.002

[26] Yavari N, Tang AM, Pereira JM, et al (2014) A simple method for numerical modelling of energy pile's mechanical behavior. Géotechnique Lett 4(April-June):119-124. doi: 10.1680/geolett.13.00053

[27] Suryatriyastuti ME, Mroueh H, Burlon S (2012) Understanding the temperature-induced mechanical behaviour of energy pile foundations. Renew Sust Energ Rev 16(5): 3344-3354. doi:10.1016/j.rser.2012.02.062

[28] Salciarini D, Ronchi F, Cattoni E, et al (2013) Thermomechanical effects induced by energy piles operation in a small piled raft. Int J Geomech 15(2):04014042. doi:10.1061/(ASCE)GM.1943-5622.0000375.

[29] Gashti EHN, Malaska M, Kujala K (2014) Evaluation of thermo-mechanical behaviour of 
composite energy piles during heating/cooling operations. Eng Struct 75:363-373. doi:10.1016/j.engstruct.2014.06.018

[30] Amatya BL, Soga K, Bourne-Webb PJ, et al (2012) Thermo-mechanical behaviour of energy piles. Géotechnique 62(6): 503-519. doi:10.1680/geot.10.P.116

[31] Bourne-Webb PJ, Freitas TMB, da Costa Gonçalves RA (2016) Thermal and mechanical aspects of the response of embedded retaining walls used as shallow geothermal heat exchangers. Energ Buildings 125:130-141. doi: 10.1016/j.enbuild.2016.04.075

[32] Sterpi D, Coletto A, Mauri L (2017) Investigation on the behaviour of a thermo-active diaphragm wall by thermo-mechanical analyses. Geomech Eng En 9:1-20. doi: 10.1016/j.gete.2016.10.001

[33] Olgun CG, Ozudogru TY, Arson CF (2014) Thermo-mechanical radial expansion of heat exchanger piles and possible effects on contact pressures at pile-soil interface. Géotechnique Lett 4(3):170-178. doi:10.1680/geolett.14.00018

[34] Ozudogru TY, Olgun CG, Arson CF (2015) Analysis of friction induced thermo-mechanical stresses on a heat exchanger pile in isothermal soil. Geotech Geol Eng 33(2):357-371. doi:10.1007/s10706-014-9821-0

[35] Yin S, Towler BF, Dusseault MB, et al (2009) Numerical experiments on oil sands shear dilation and permeability enhancement in a multiphase thermoporoelastoplasticity framework. J Petrol Sci Eng 69(3):219-226. doi:10.1016/j.petrol.2009.08.017

[36] Karthigeyan S, Ramakrishna V, Rajagopal K (2006) Influence of vertical load on the lateral response of piles in sand. Comput Geotech 33(2):121-131. 
doi:10.1016/j.compgeo.2005.12.002

[37] Allan ML (2000) Materials characterization of superplasticized cement-sand grout. Cement Concrete Res 30(6):937-942. doi:10.1016/S0008-8846(00)00275-1

[38] Hazzar L, Nhussien M, Karray M (2017) Influence of vertical loads on lateral response of pile foundations in sands and clays. Journal of Rock Mechanics and Geotechnical Engineering 9(2):291-304. doi: 10.1016/j.jrmge.2016.09.002

[39] Hussien MN, Tobita T, Iai S, et al (2014) On the influence of vertical loads on the lateral response of pile foundation. Comput Geotech 55(1):392-403. doi: 10.1016/j.compgeo.2013.09.022

[40] Reddy SB, Krishna AM (2015) Recycled Tire Chips Mixed with Sand as Lightweight Backfill Material in Retaining Wall Applications: An Experimental Investigation. Int J of Geosynth and Ground Eng 1(4):31. doi:10.1007/s40891-015-0036-0

[41] Lee KH, Cho JY, Salgado R, Lee I (2001) Retaining wall model test with waste foundry sand mixture backfill, Geotech Test J 24:401-408. doi: 10.1520/GTJ11137J

[42] Schad H, Vermeer PA, Lächler A (2007) Fresh concrete pressure in diaphragm wall panels and resulting deformations. In: Grosse, Ch. U. (Ed.): Advances in Construction Materials, Berlin: Springer Verlag, 2007:505-512.

[43] Sun M, Xia C, Zhang G (2013) Heat transfer model and design method for geothermal heat exchange tubes in diaphragm walls. Energ Buildings 61(6):250-259. doi: 10.1016/j.enbuild.2013.02.017

[44] Di Donna A, Barla M (2016) The role of ground conditions on energy tunnels' heat 
exchange. ICE Env. Geotech., 3, 214-224. doi:10.1680/jenge.15.00030

[45] Dupray F, Baehler M, Laloui L (2013) Effect of groundwater flow on the THM behavior of an energy pile. Proc. Int. Symp. Coupled Phenomena in Environmental Geotechnics, Turin (Italy), 483-489. doi:10.1201/b15004-63

[46] Dubroca B, Duffa G, Leroy B (2002, September) High Temperature Mass and Heat Transfer Fluid-Solid Coupling. In AIAA/AAAF 11th International Space Planes and Hypersonic Systems and Technologies Conference, 5124.

[47] Khoury RRE, Errera M, Khoury KE, et al (2017) Efficiency of coupling schemes for the treatment of steady state fluid-structure thermal interactions. Int J Therm Sci 115:225-235. doi: 10.1016/j.ijthermalsci.2017.02.001

[48] Jeong S, Lim H, Lee J K, et al (2014) Thermally induced mechanical response of energy piles in axially loaded pile groups. Appl Therm Eng 71(1):608-615. doi:10.1016/j.applthermaleng.2014.07.007

[49] Laloui L (2001) Thermo-mechanical behaviour of soils. Revue Française De Génie Civil 5(6):809-843.

[50] Cekerevac C, Laloui L (2004) Experimental study of thermal effects on the mechanical behaviour of a clay. Int J Numer Anal Met 28(3):209-228. doi: 10.1002/nag.332

[51] Laloui L, Cekerevac C, François B (2005) Constitutive modelling of the thermo-plastic behaviour of soils. Revue Européenne De Génie Civil 9(5-6):635-650.

[52] Tang AM, Cui YJ, Barnel N (2008) Thermo-mechanical behaviour of a compacted swelling clay. Géotechnique 58(1):45-54. doi: 10.1680/geot.2008.58.1.45 
[53] Hong PY, Pereira J-M, Tang AM, Cui YJ (2013) On some advanced thermo-mechanical 